ZAPISKI HistoryCZNE t. 85, 2020, z. 2, s. 157-174

ISSN 0044-1791

http://dx.doi.org/10.15762/ZH.2020.19

MAREK JODKOWSKI*

(iD) https://orcid.org/0000-0001-9793-9935

\title{
DUSZPASTERSTWO WOJSKOWE NA OBSZARZE DIECEZJI WARMIŃSKIEJ W PIERWSZEJ POŁOWIE XIX WIEKU
}

\author{
Abstract \\ Military Chaplaincy in the Diocese of Warmia \\ in the First Half of the Nineteenth Century
}

The historiography of the Diocese of Warmia has so far lacked a study on military chaplaincy in the first half of the nineteenth century. In order to investigate this issue, an analysis of the documentation stored at the Geheimes Staatsarchiv Preussischer Kulturbesitz in Berlin has been conducted. The results of the study demonstrated that the Catholic military chaplaincy began to recover after the Napoleonic campaign of 1806-1807. In 1810, Catholic priests performed regular ministerial service in four cities. However, in 18 garrisons services were not performed. As a result, soldiers could receive their sacraments in Catholic churches only if they obtained passes. The first legal solutions of 1811 did not provide for the existence of a Catholic chaplaincy during peacetime. Some significant changes occurred in 1832. In the absence of a military chaplain, a clergyman working in a civil parish was to take over his function. By the end of that year, priests from Warmia served regularly in garrisons in Braniewo, Elblag, Klaipeda, Konigsberg, Malbork and Tilsit. Another 15 garrisons were to receive a chaplain. Some of them served in several garrisons. The issue of financing military chaplains remained unresolved for quite a long time. In February 1835, the Minister of War, Job von Witzleben, informed that chaplains recruited from the diocesan clergy received allowances, reimbursement for travel expenses and four thalers for their chaplaincy. However, some military places of worship suffered from a shortage of liturgical equipment.

Keywords: Prussian army; Diocese of Warmia; military chaplaincy; military chaplains; East Prussia; nineteenth century

\footnotetext{
* Wydział Teologii, Uniwersytet Warmińsko-Mazurski w Olsztynie,

@ marek.jodkowski@uwm.edu.pl;ksmarekj@wp.pl
} 
Fryderyk Wilhelm III uważał się za głęboko religijnego wyznawcę protestantyzmu. Z tego względu dokładał starań, aby Prusy zachowały swój protestancki charakter. Wobec Kościoła katolickiego przejawiał nieżyczliwą postawę, dając niejednokrotnie wyraz swoim antykatolickim przekonaniom. Energicznie zaprzeczał pogłoskom, jakoby miał się przychylać ku tej konfesji, twierdząc, że stroni od niej ze względu na kultywowane przez nią niezliczone, antybiblijne aksjomaty („antibiblische Lehrsätze”). Katolicyzm postrzegał jako wynaturzenie chrześcijaństwa („Entartung”). Ten sceptycyzm nie powstrzymał go jednak przed dostrzeganiem potrzeb religijnych wyrażanych przez żołnierzy tego wyznania $^{1}$. Aby zagwarantować im udział w życiu sakramentalnym, dopuszczał możliwość korzystania przez nich z posługi kapłańskiej w jednostkach wojskowych bądź w świątyniach znajdujących się poza garnizonem.

$\mathrm{Na}$ temat duszpasterstwa wojskowego w diecezji warmińskiej w XIX w. pisał ks. Andrzej Kopiczko. Skupił on się jednak na dość dobrze udokumentowanym czasie drugiej połowy tego stulecia ${ }^{2}$. Nieocenione wiadomości odnoszące się do opieki duchowej nad żołnierzami w pierwszej połowie XIX w. zaprezentował Heinrich Pohl ${ }^{3}$. Dotyczyły one jednak Kościoła katolickiego w Niemczech en bloc, a nie poszczególnych diecezji, a tym bardziej diecezji warmińskiej. Z tego względu warto uzupełnić te informacje, przeprowadzając analizę dokumentów odnoszących się do katolickiego duszpasterstwa wojskowego na obszarze Prus Wschodnich, które zdeponowano w Geheimes Staatsarchiv Preussicher Kulturbesitz w Berlinie. Zebrano je w jednostce archiwalnej opatrzonej datami skrajnymi 1832-1863, wytworzonej w pruskim Ministerstwie Wyznań Religijnych, Oświaty i Zdrowia ${ }^{4}$. Oryginalny tytuł, znajdujący się na okładce jednostki, stanowiącej poszyt, brzmi następująco: Acta betreffend: die kirchlichen Angelegenheiten der katholischen Glaubensgenossen beim Militär und die Wahrnehmung der Seelsorge derselben anzustellenden katholischen Geistlichen und Kirchenbedienten in der Provinz Preußen. Wewnątrz zachowano układ chronologiczny pism. Jednostka ta posiada 303 karty, opatrzone ciągłą numeracją. W poszycie znajdują się akta odnoszące się do prowincji Prusy, obejmującej poza diecezją warmińską również diecezję chełmińską. Dotychczas nie cieszyły się one szczególnym zainteresowaniem historyków.

${ }^{1}$ Heinrich PoHL, Die katholische Militärseelsorge Preussens 1797-1888, Amsterdam 1962, s. $1-2$.

${ }^{2}$ Zob. zwłaszcza Andrzej Kopiczкo, Duchowieństwo katolickie diecezji warmińskiej w latach 1821-1945, cz. 1: Studium prozopograficzne, Olsztyn 2004, s. 191-201.

${ }^{3}$ H. PoHL, op.cit., passim.

${ }^{4}$ Geheimes Staatsarchiv Preussicher Kulturbesitz, Berlin-Dahlem (dalej cyt. GStA PK), I. Hauptabteilung (dalej cyt. I. HA), Rep. 76 Kultusministerium IV (dalej cyt. Rep. 76 IV), Sekt. 2, Abt. VIII, Nr. 1, Bd. 1. 
Niniejsze opracowanie odnosi się do obszarów, które po ogłoszeniu w 1821 r. przez papieża Piusa VII bulli De salute animarum znalazły się w granicach diecezji warmińskiej. Do tego czasu tereny położone na północ od Pregoły należały do diecezji sambijskiej. Podlegały one jednak, jak również 2/3 ziem diecezji warmińskiej, sprotestantyzowanych przez księcia pruskiego Albrechta Hohenzollerna, jurysdykcji kościelnej biskupa warmińskiego. Oczywiście wspomniana bulla włączała do diecezji warmińskiej także cały oficjalat pomezański z siedzibą w Malborku ${ }^{5}$ Warto również zaznaczyć, że strukturalne duszpasterstwo wojskowe w ramach Kościoła katolickiego w Prusach powołano dopiero na skutek zmian spowodowanych Wiosną Ludów ${ }^{6}$. Łączyło się ono ze stopniowym wprowadzeniem nomenklatury określającej duszpasterzy sprawujących opiekę nad żołnierzami. Na potrzeby artykułu posłużono się jednak powszechnie stosowaną nazwą kapelana wojskowego, oznaczającego w tym przypadku duszpasterza diecezjalnego sprawującego w miarę regularną posługę wśród członków wojska.

\section{GENEZA ERYGOWANIA DUSZPASTERSTWA WOJSKOWEGO}

Po kampanii napoleońskiej z lat 1806-1807 zręby dotychczasowego duszpasterstwa wojskowego sprawowanego przez duchowieństwo katolickie legły w gruzach. Nie angażowano księży tego wyznania, aby nieśli pomoc duchową żołnierzom. W żadnym garnizonie pruskim, jak stwierdził H. Pohl, nie odprawiano mszy św. Dotkliwy brak wsparcia duszpasterskiego spowodował, że już w 1809 r. postulowano uregulowanie tej sprawy. Tego roku komendant z Piławy, major von Treskow, zabiegał, aby władze wojskowe udzieliły pozwolenia na mszę św. w tamtejszym garnizonie, którą raz w roku celebrowałby ksiądz diecezjalny z Królewca. Nie otrzymywałby za to żadnego wynagrodzenia. Ostatecznie jednak Ministerstwo Spraw Wewnętrznych udzieliło zgody nie tylko na posługę duchownego, lecz także na wypłacenie mu rekompensaty za podróż i wyżywienie. Następnie, za aprobatą Fryderyka Wilhelma III, zagwarantowano mu darmowy zaprzęg na czas jego posługi oraz roczne wynagrodzenie w wysokości ośmiu talarów ${ }^{7}$.

Kolejne nieocenione informacje dotyczące duszpasterstwa wojskowego wyszły spod pióra cytowanego H. Pohla. Opublikował on mianowicie doku-

${ }^{5}$ Biskupi warmińscy otrzymali od papieża Pawła V jurysdykcję nad diecezją sambijską już w 1617 r.; zob. Andrzej Kopiczкo, Rozwój Kościoła katolickiego na terytorium dzisiejszego Obwodu Kaliningradzkiego (do 1947 r.). Zarys problematyki, [in:] Czynem i prawdą. Ksiega pamiątkowa na siedemdziesiąte piąte urodziny księdza arcybiskupa Edmunda Piszcza, red. Cyprian Rogowski, Władysław Nowak, Andrzej Kopiczko, Olsztyn 2004, s. 101; idem, Ustrój i organizacja diecezji warmińskiej w latach 1525-1772, Olsztyn 1993, s. 46, 194; idem, Duchowieństwo katolickie diecezji warmińskiej, s. 15.

${ }^{6}$ Idem, Duchowieństwo katolickie diecezji warmińskiej, s. 191.

${ }^{7}$ H. PoHL, op.cit., s. 27-28. 
ment z $1810 \mathrm{r}$., będący sumarycznym zestawieniem dotyczącym posługi katolickich duchownych w garnizonach wojskowych na obszarze Prus Wschodnich.

Tab. 1. Garnizony z regularną posługą duszpasterzy katolickich w Prusach Wschodnich w $1810 \mathrm{r}$.

\begin{tabular}{|c|l|c|}
\hline Garnizon & \multicolumn{1}{|c|}{ Rodzaj jednostki korpusu } & $\begin{array}{c}\text { Liczba katolickich } \\
\text { żołnierzy }\end{array}$ \\
\hline 1 & \multicolumn{1}{|c|}{2} & 3 \\
\hline Braniewo & $\begin{array}{l}\text { batalion fizylierów } \\
\text { 2 Wschodniopruskiego Pułku Piechoty }\end{array}$ & 16 \\
\hline Kłajpeda & $\begin{array}{l}\text { batalion fizylierów } \\
\text { 1 Wschodniopruskiego Pułku Piechoty }\end{array}$ & 30 \\
\hline Królewiec & 1 Wschodniopruski Pułk Piechoty & 41 \\
\hline Królewiec & 2 Wschodniopruski Pułk Piechoty & 46 \\
\hline Królewiec & Wschodniopruski Pułk Kirasjerów & 16 \\
\hline Królewiec & 10 Kompania Artyleryjska & 684 \\
\hline Tylża & 2 Szwadron Litewskiego Pułku Dragonów & 39 \\
\hline & Lącznie: & 872 \\
\hline
\end{tabular}

Źródło: Heinrich PoHL, Die katholische Militärseelsorge Preussens 1797-1888, Amsterdam 1962, s. 34-35.

Z tabeli 1 wynika, że w $1810 \mathrm{r}$. księża katoliccy sprawowali regularną posługę duszpasterską $\mathrm{w}$ siedmiu jednostkach militarnych zlokalizowanych w czterech miastach na obszarze diecezji sambijskiej i warmińskiej. Najwięcej katolickich żołnierzy objętych tą opieką stacjonowało w Królewcu (787), a najmniej - w Braniewie (16).

Tab. 2. Garnizony na obszarze diecezji sambijskiej i warmińskiej bez regularnej posługi duszpasterskiej w $1810 \mathrm{r}$.

\begin{tabular}{|c|l|c|}
\hline Garnizon & \multicolumn{1}{|c|}{ Rodzaj jednostki korpusu } & $\begin{array}{c}\text { Liczba katolickich } \\
\text { żołnierzy }\end{array}$ \\
\hline 1 & \multicolumn{1}{|c|}{2} & 3 \\
\hline Bartoszyce & $\begin{array}{l}\text { 2 Kompania } \\
\text { I Wschodniopruskiego Batalionu Grenadierów }\end{array}$ & 12 \\
\hline Cynty & $\begin{array}{l}\text { 2 Pododdział (Abteilung) } \\
\text { 4 Wschodniopruskiej Kompanii Inwalidów }\end{array}$ & 56 \\
\hline Darkiejmy & 1 Szwadron 2 Przybocznego Pułku Huzarów & - \\
\hline Domnowo & służba kwaterunkowa & - \\
\hline $\begin{array}{c}\text { Fort Lyck } \\
\text { (Czarci } \\
\text { Ostrów) }\end{array}$ & $\begin{array}{l}\text { Dowództwo 2 Zachodniopruskiej } \\
\text { Kompanii Inwalidów }\end{array}$ & \\
\hline
\end{tabular}




\begin{tabular}{|c|l|c|}
\hline 1 & \multicolumn{1}{|c|}{2} & 3 \\
\hline Gąbin & 1 Szwadron 2 Przybocznego Pułku Huzarów & 1 \\
\hline Gołdap & 1 Szwadron 2 Przybocznego Pułku Huzarów & 3 \\
\hline $\begin{array}{c}\text { Iławka } \\
\text { Pruska }\end{array}$ & 2 Wschodniopruska Kompania Inwalidów & 72 \\
\hline Kętrzyn & $\begin{array}{l}\text { 2 Kompania } \\
\text { I Wschodniopruskiego Batalionu Grenadierów }\end{array}$ & 8 \\
\hline Orzysz & $\begin{array}{l}\text { 2 Pododdział (Abteilung) } \\
\text { 2 Zachodniopruskiej Kompanii Inwalidów }\end{array}$ & 72 \\
\hline Piława & Wschodniopruski Batalion Garnizonowy & 73 \\
\hline Piława & 1 Kompania Artyleryjska & 92 \\
\hline Pisz & 2 Zachodniopruska Kompania Inwalidów & 31 \\
\hline $\begin{array}{c}\text { Rybaki (niem. } \\
\text { Fischhausen) }\end{array}$ & 4 Wschodniopruska Kompania Inwalidów & 39 \\
\hline Stołupiany & 1 Szwadron 2 Przybocznego Pułku Huzarów & 8 \\
\hline Szczytno & 3 Wschodniopruska Kompania Inwalidów & 24 \\
\hline Tapiewo & 1 Wschodniopruska Kompania Inwalidów & 36 \\
\hline Wielbark & $\begin{array}{l}\text { 2 Pododdział (Abteilung) } \\
\text { 3 Wschodniopruskiej Kompanii Inwalidów }\end{array}$ & 21 \\
\hline Wystruć & 1 Szwadron Litewskiego Pułku Dragonów & 610 \\
\hline \multicolumn{2}{|l}{ Łącznie: }
\end{tabular}

Źródło: Heinrich РонL, Die katholische Militärseelsorge Preussens 1797-1888, Amsterdam 1962, s. 34-35.

W $1810 \mathrm{r}$. bez regularnej posługi duszpasterskiej pozostawało 18 garnizonów. Wszystkie znajdowały się bądź na obszarze sprotestantyzowanej niegdyś części diecezji warmińskiej, bądź diecezji sambijskiej. W miejscowościach tych, należących do diaspory katolickiej, nie było w tym czasie placówek duszpasterskich. Najwięcej katolickich żołnierzy stacjonowało w Piławie (165). Żaden katolik nie służył w Domnowie ani w Forcie Lyck, natomiast jednego żołnierza tego wyznania odnotowano w Gąbinie.

Heinrich Pohl informował, że w celach religijnych katoliccy żołnierze z Bartoszyc odbywali podróże do oddalonego o półtorej mili klasztoru Neukirch. Najprawdopodobniej nastąpiła tutaj pomyłka. Najbliższy klasztor znajdował się w Stoczku Warmińskim, oddalonym jednak od Bartoszyc o ponad dwie i pół mili. Żołnierze mogli korzystać z posługi sakramentalnej w Krekolach, położonych w odległości dwóch mil. Znacznie później, bo dopiero na początku XX w. wybudowano należącą do tej parafii kaplicę we wsi Samolubie, której odległość od Bartoszyc wynosiła półtorej mili. Żołnierze z Kętrzyna

${ }^{8}$ Ibid., s. 35; Rocznik Diecezji Warmińskiej, 1985, s. 268. 
udawali się z kolei do klasztoru w Świętej Lipcę. Oczywiście po kasacie jezuitów administrowali tamtejszą świątynią księża diecezjalni ${ }^{10}$. Jeśli chodzi o Wystruć, kilkakrotnie w ciągu roku odwiedzał ten garnizon ksiądz z Tylży ${ }^{11}$. Tu również należy się wyjaśnienie. Duszpasterz, który opiekował się katolikami w tym mieście, mieszkał we wsi Drangowski pod Tylżą. Budowę kościoła katolickiego w Tylży rozpoczęto dopiero w $1847 \mathrm{r}^{12}$ Dowódcy szwadronów płacili temu księdzu 10 talarów rocznie za posługę kapłańską wśród członków wojska ${ }^{13}$.

Pohl zapisał, że duchowni ze Świętej Lipki roztoczyli opiekę duszpasterską nad żołnierzami w Gołdapi, Darkiejmach i Stołupianach. Wprawdzie w XVIII w. tamtejsi jezuici odwiedzali katolicką ludność m.in. w Gołdapi i Darkiejmach ${ }^{14}$, jednak po ich kasacie aż do (prawdopodobnie) pierwszego dziesięciolecia XIX w. księża diecezjalni pracujący w Świętej Lipce mieli odbywać dwukrotnie w ciągu roku podróże duszpasterskie do czterech wschodniopruskich miast: Rynu, Giżycka, Węgorzewa i Nordenburga ${ }^{15}$. Adnotacja H. Pohla rzuca zatem nowe światło na zakres posługi świętolipskiego duchowieństwa. Z kolei stacjonujący niegdyś w Gąbinie pułk dowodzony przez von Courbière’a miał własnego katolickiego duchownego, który był opłacany z funduszu królewskiego. Opiekował się on również katolikami w Forcie Lyck, Orzyszu i Piszu. Wiadomo także, że duszpasterz przyjeżdżający z Królewca do Piławy otrzymywał od każdej jednostki jednego talara rocznie. W październiku 1809 r. należność wypłaciło mu prawdopodobnie Pruskie Ministerstwo Wojny. Katoliccy żołnierze z Rybak korzystali z posługi sakramentalnej w Królewcu ${ }^{16}$.

Dość ważne wydają się informacje przytoczone w 1849 r. na łamach „Katholisches Wochenblatt". Wynika $\mathrm{z}$ nich mianowicie, że w latach 1811-1815 w Piszu, Orzyszu, Nordenborku i Srokowie stacjonowali weterani („Militair-Veteranen"). Ponieważ byli wśród nich katolicy, zobligowano świętolipskich księży do celebracji w tych miejscach mszy św. raz w roku. Duchowni mieli

${ }^{9}$ H. Pohl, op.cit., s. 35.

${ }^{10}$ Rocznik Diecezji Warmińskiej, 1985, s. 239.

${ }^{11}$ H. Pohl, op.cit., s. 35.

${ }^{12}$ Johannes Zaberman, Die Mission in Litthauen, Katholisches Wochenblatt, 1852, Nr. 50, s. 240; zob. także Marek JodKowski, Katolicka parafia w Tylży w XIX wieku, Studia Redemptorystowskie, nr 13: 2015, s. 359.

${ }^{13}$ H. PoHL, op.cit., s. 35.

${ }^{14}$ Zob. zwłaszcza A. Kopıczko, Ustrój i organizacja diecezji warmińskiej, s. 198.

${ }^{15}$ Gustav Schmidt, Kurze Darstellung der Mission in Masuren (Fortsetzung), Katholisches Wochenblatt, 1849, Nr. 3, s. 12.

${ }^{16}$ H. PoHL, op.cit., s. 35. 
otrzymywać rekompensatę za podróż oraz diety. Z ich posługi korzystała przy okazji ludność cywilna. W 1815 r. weterani opuścili Pisz, co wiązało się z zaprzestaniem celebrowania nabożeństw katolickich w tym mieście. Zgodnie z cytowanymi adnotacjami księża katoliccy jeździli jedynie do Nordenborka i Srokowa, gdzie umieszczono kompanię inwalidów ${ }^{17}$. Z kolei ks. Augustin Kolberg podaje, że w tym czasie duchowni ci odwiedzali z posługą religijną, poza Piszem i Srokowem, także Orzysz, Szczytno i Wielbark. Ich posługa obejmowała początkowo jedynie członków wojska, potem zaś została rozszerzona na ludność cywilną zamieszkującą inne miasta wschodniopruskie ${ }^{18}$.

\section{PRÓBY WPROWADZENIA TRWAŁYCH REGULACJI PRAWNYCH DOTYCZĄCYCH DUSZPASTERSTWA WOJSKOWEGO}

Pierwsze rozwiązania prawne w XIX w. dotyczące duszpasterstwa wojskowego w Prusach ogłoszono 28 III 1811 r. Stanowiły one, że zarówno katolicy, jak i ewangelicy reformowani mogli powierzyć opiekę nad żołnierzami finansowanemu przez siebie duchownemu. Miał on jednak podlegać ewangelickiemu proboszczowi garnizonowemu. Wojskową kapelanię katolicką przewidziano tylko na czas wojny ${ }^{19}$. Gdy przygotowywano się do inwazji na Rosję w 1812 r., król pruski zezwolił, aby przy tworzonym korpusie ustanowić katolickiego duszpasterza mówiącego dodatkowo po polsku. Z tego względu 1 VI 1812 r. zwrócono się do biskupa nominata Józefa Hohenzollerna, aby wyłonił odpowiedniego kandydata. Wprawdzie biskup potraktował tę prośbę jako dowód troski władz państwowych dotyczącej ożywienia praktyk religijnych, jednak ze względu na braki w szeregach duchowieństwa warmińskiego uchylił się od jej spełnienia ${ }^{20}$. Sekcja wyznań w Ministerstwie Spraw Wewnętrznych 12 VII 1812 r. ponownie zabiegała o pozytywną deklarację biskupa warmińskiego, tym razem dotyczącą nominacji ks. Alberta Junklewicza z Królewca na kapelana (Feldprediger) na czas trwania wojny. Biskupowi obiecano przy tym, że po przywróceniu pokoju swoją działalność reaktywują instytucje zajmujące się kształceniem teologicznym. Ostatecznie nominacja Junklewicza na kapelana została potwierdzona („zum katholischen Feldgeistlichen oder

${ }^{17}$ G. SchmidT, op.cit., s. 12. Informację o celebracjach eucharystycznych w Piszu w $1811 \mathrm{r}$. potwierdził ks. Johannes Minarski w 1924 r.; zob. Marek JoDkowski, Dzieje placówki duszpasterskiej w Piszu przed II wojną światową, Studia Ełckie, t. 14: 2012, s. 233, przyp. 2.

${ }^{18}$ Augustin Kolberg, Geschichte der Heiligenlinde, Zeitschrift für die Geschichte und Altertumskunde Ermlands, Bd. 3: 1866, s. 510.

${ }^{19}$ A. Kopiczкo, Duchowieństwo katolickie diecezji warmińskiej, s. 191; Johannes GüsGEN, Die katholische Militärseelsorge in Deutschland zwischen 1920 und 1945, Köln-Wien 1989, s. 20.

${ }^{20}$ H. PoHL, op.cit., s. 56. 
Feldprediger bei dem gegen die Russen ins Feld gerückten, unter dem Befehle des Herrn Generalmajors v. York in Curland stehenden Truppenkorps"). Miał on otrzymywać 20 talarów miesięcznie w czasie kampanii wojennej, a także racje i porcje przysługujące protestanckim kapelanom wojskowym (Feldgeistlichen). Junklewicz nie wyruszył jednak na wojnę. Przesłał atest wyjaśniający, że z powodu złego stanu zdrowia nie może objąć tej posady ${ }^{21}$.

Zwiastunem wprowadzenia we wschodnich diecezjach pruskich zorganizowanej opieki pastoralnej nad osobami pełniącymi służbę wojskową była decyzja konsystorza w Gdańsku z 4 XI 1831 r. o wyborze duchownych na kapelanów tych garnizonów, które nie miały własnego księdza. Wprawdzie postanowienie to dotyczyło Kościołów protestanckich, jednak dość szybko adresatem nowych regulacji prawnych stali się również katolicy. Minister wyznań religijnych, oświaty i zdrowia zaaprobował tę decyzję 17 IV $1832 \mathrm{r}^{22}$

Duszpasterstwo wojskowe regulował nowy Wojskowy Porzadek Kościelny (Militair-Kirchen-Ordnung) z 12 II $1832 \mathrm{r}^{23} \mathrm{~W}$ paragrafie piątym wyraźnie zaznaczono, że chodzi zarówno o ewangelickich, jak i katolickich duchownych pracujących w parafiach cywilnych, którzy przy braku kapelana wojskowego mieli objąć jego funkcję, wraz ze wszystkimi wynikającymi z tego tytułu zobowiązaniami oraz przywilejami. W związku z tym 25 VI 1832 r. minister Karl von Altenstein zobowiązał konsystorz królewiecki do uzgodnienia tej sprawy zarówno z władzami wojskowymi, jak i kościelnymi ${ }^{24}$. Gotowość do realizacji decyzji ministerialnych dowództwo I Korpusu Armijnego zgłosiło w październiku 1832 r. Do prośby konsystorza dość długo nie ustosunkował się jednak biskup Hohenzollern ${ }^{25}$.

Respektowana przynajmniej od pierwszego dziesięciolecia XIX w. praktyka, jak też nowe regulacje prawne powodowały, że w przypadku braku posługi duszpasterskiej $\mathrm{w}$ garnizonach żołnierze otrzymywali przepustki, aby zadośćuczynić potrzebom religijnym w świątyniach katolickich, o czym informuje tabela 3 .

${ }^{21}$ Ibid., s. 57-58.

${ }^{22}$ GStA PK, I. HA, Rep. 76 IV, Sekt. 2, Abt. VIII, Nr. 1, Bd. 1, k. 1.

${ }^{23}$ Zob. J. M. Claessen, Andreas Räss, Nikolaus von WeIs, Beiträge zur Kirchengeschichte des neuesten Jahrhunderts in Deutschland oder über die neuesten kirchlichen Verhältnisse daselbst, Augsburg 1835, s. 85; Ernst R. Huber, Wolfgang Huber, Staat und Kirche im 19. und 20. Jahrhundert. Dokumente zur Geschichte des deutschen Staatskirchenrechts, Bd. 1: Staat und Kirche vom Ausgang des alten Reichs bis zum Vorabend der bürgerlichen Revolution, Berlin 1990, s. 587.

${ }^{24}$ GStA PK, I. HA, Rep. 76 IV, Sekt. 2, Abt. VIII, Nr. 1, Bd. 1, k. 2-2v.

${ }^{25}$ Ibid., k. 4. 
Tab. 3. Garnizony na obszarze diecezji warmińskiej wydające żołnierzom katolickim przepustkę w celach religijnych (stan na 30 V 1833 r.)

\begin{tabular}{|c|c|c|c|c|}
\hline Lp. & Garnizon & Rodzaj jednostki korpusu & $\begin{array}{l}\text { Liczba } \\
\text { przepustek } \\
\text { na osobę } \\
\text { w roku }\end{array}$ & $\begin{array}{c}\text { Docelowe } \\
\text { miejsce posługi } \\
\text { sakramentalnej }\end{array}$ \\
\hline 1 & 2 & 3 & 4 & 5 \\
\hline 1 & Bartoszyce & $\begin{array}{l}\text { trzon I Batalionu } 4 \text { Pułku Land- } \\
\text { wehry }\end{array}$ & 2 & $\begin{array}{c}\text { Lidzbark } \\
\text { Warmiński }\end{array}$ \\
\hline 2 & Domnowo & $\begin{array}{l}\text { pododdział specjalny (Detache- } \\
\text { ment) } 1 \text { Kompanii Inwalidów }\end{array}$ & 2 & $\begin{array}{c}\text { Lidzbark } \\
\text { Warmiński }\end{array}$ \\
\hline 3 & Gąbin & $\begin{array}{l}\text { trzon II Batalionu (Gąbiński) } \\
3 \text { Pułku Landwehry }\end{array}$ & 2 & Drangowski \\
\hline 4 & $\begin{array}{l}\text { Norden- } \\
\text { bork }\end{array}$ & $\begin{array}{l}\text { pododdział specjalny (Detache- } \\
\text { ment) } 1 \text { Kompanii Inwalidów }\end{array}$ & 1 & Święta Lipka \\
\hline 5 & Pasłęk & $\begin{array}{l}\text { trzon II Batalionu } 4 \text { Pułku } \\
\text { Landwehry }\end{array}$ & 2 & Elbląg \\
\hline 6 & Srokowo & $\begin{array}{l}\text { pododdział specjalny (Detache- } \\
\text { ment) } 1 \text { Kompanii Inwalidów }\end{array}$ & 1 & Święta Lipka \\
\hline 7 & Szczytno & $\begin{array}{l}\text { trzon I Batalionu } 3 \text { Pułku Land- } \\
\text { wehry }\end{array}$ & & $\begin{array}{l}\text { Biskupiec } \\
\text { Reszelski }\end{array}$ \\
\hline 8 & Tapiewo & $\begin{array}{l}2 \text { Pododdział (Abteilung) } \\
1 \text { Kompanii Inwalidów }\end{array}$ & 2 & 2 Welawa \\
\hline 9 & Węgorzewo & $\begin{array}{l}\text { trzon III Batalionu (Węgo- } \\
\text { rzewski) } 3 \text { Pułku Landwehry }\end{array}$ & 2 & Święta Lipka \\
\hline
\end{tabular}

Źródło: Geheimes Staatsarchiv Preussicher Kulturbesitz, Berlin-Dahlem, I. Hauptabteilung, Rep. 76 Kultusministerium IV, Sekt. 2, Abt. VIII, Nr. 1, Bd. 1, k. 13v-14.

W 1833 r. na obszarze diecezji warmińskiej zwalniano żołnierzy na przepustkę w celach religijnych w dziewięciu garnizonach. Docierali oni niejednokrotnie do miejsc, które leżały dalej niż najbliższa świątynia katolicka. Szczególną popularnością cieszyła się Święta Lipka, która stała się docelowym miejscem posługi sakramentalnej dla trzech garnizonów. Na ogół wydawano dwie przepustki $w$ celach religijnych na osobę $w$ ciągu roku. Żołnierzy stacjonujących w Nordenborku i Srokowie zwalniano raz w roku, ponieważ po raz drugi mogli oni wziąć udział w nabożeństwach sprawowanych dla ludności cywilnej $\mathrm{w}$ ich miastach garnizonowych ${ }^{26}$. $\mathrm{Z}$ kolei żołnierze $\mathrm{z}$ Tapiewa mieli możliwość uczestnictwa $\mathrm{w}$ dwóch mszach św. celebrowanych w tym mieście

\footnotetext{
${ }^{26}$ Ibid., k. 14.
} 
dla ludności cywilnej, w miejscu określanym jako „Gandarmen Haus” ${ }^{\text {”2 }}$. Najprawdopodobniej nie wyjeżdżali oni do Welawy, jak odnotowano w tabeli 3 , ponieważ nie prowadzono w tym mieście stałego duszpasterstwa katolickiego.

W 1833 r. informowano ponadto, że na obszarze całej prowincji pruskiej liczba żołnierzy pozbawionych opieki kapelana katolickiego wynosiła 389. Stacjonowali oni w 22 miejscowościach. W takich garnizonach, jak Bartoszyce, Domnowo, Nordenbork, Pasłęk, Szczytno i Węgorzewo, wyznanie katolickie deklarowało przeciętnie od jednej do czterech osób. Warto nadmienić, że liczba żołnierzy tego wyznania w I Korpusie Armijnym opiewała w tym czasie na 3055, co stanowiło $19 \%$ wszystkich jego członków ${ }^{28}$.

\section{KSIĘŻA WARMIŃSCY W DUSZPASTERSTWIE WOJSKOWYM}

Pod koniec 1832 r. biskup Józef Hohenzollern przedłożył konsystorzowi królewieckiemu listę garnizonów na obszarze diecezji warmińskiej, w których celebrowano katolickie nabożeństwa. Wymienił również księży, którzy wyrazili gotowość pełnienia posługi duszpasterskiej wśród żołnierzy pozbawionych tego rodzaju opieki.

Tab. 4. Duchowni diecezji warmińskiej sprawujący regularną posługę sakramentalną w garnizonach pod koniec $1832 \mathrm{r}$.

\begin{tabular}{|c|c|c|c|c|}
\hline Lp. & Garnizon & $\begin{array}{c}\text { Liczba } \\
\text { żołnierzy } \\
\text { katolickich }\end{array}$ & $\begin{array}{c}\text { Stosunek liczbowy } \\
\text { zołnierzy katolickich } \\
\text { do protestanckich }\end{array}$ & $\begin{array}{c}\text { Katoliccy duchowni } \\
\text { pełniący posługe } \\
\text { sakramentalną }\end{array}$ \\
\hline 1 & 2 & 3 & 4 & 5 \\
\hline 1 & Braniewo & 109 & $1 / 8$ & $\begin{array}{c}\text { archiprezbiter } \\
\text { Andreas Schröter }\end{array}$ \\
\hline 2 & Elbląg & 163 & $1 / 5$ & proboszcz Andreas Rehaag \\
\hline 3 & Kłajpeda & 20 & $1 / 34$ & $\begin{array}{c}\text { komendariusz } \\
\text { Franz Kwasniewski }\end{array}$ \\
\hline 4 & Królewiec & 375 & $1 / 9$ & $\begin{array}{c}\text { miejscowy proboszcz } \\
\text { (wówczas vacat) }\end{array}$ \\
\hline 5 & Malbork & 7 & $1 / 4$ & $\begin{array}{c}\text { w zastępstwie proboszcza } \\
\text { kaznodzieja } \\
\text { Johannes Müller }\end{array}$ \\
\hline 6 & Tylża & 15 & $1 / 20$ & $\begin{array}{c}\text { komendariusz Franz } \\
\text { Thiedig z Drangowskiego }\end{array}$ \\
\hline
\end{tabular}

Źródło: Geheimes Staatsarchiv Preussicher Kulturbesitz, Berlin-Dahlem, I. Hauptabteilung, Rep. 76 Kultusministerium IV, Sekt. 2, Abt. VIII, Nr. 1, Bd. 1, k. 7.

\footnotetext{
${ }^{27}$ Ibid.

${ }^{28}$ Ibid., k. 6.
} 
Zgodnie z tabelą 4 liczba katolickich żołnierzy w garnizonach, objętych posługą duszpasterską przez księży diecezji warmińskiej, wynosiła 689. Najwięcej żołnierzy stacjonowało w Królewcu (375), a najmniej - w Malborku (7). W tymże garnizonie stosunek liczbowy żołnierzy katolickich do protestanckich był największy i wynosił jeden do czterech.

Tab. 5. Propozycje obsadzenia kapelanii wojskowych przez duchownych diecezji warmińskiej pod koniec $1832 \mathrm{r}$.

\begin{tabular}{|c|c|c|c|c|}
\hline Lp. & Garnizon & $\begin{array}{c}\text { Liczba } \\
\text { żołnierzy } \\
\text { katolickich }\end{array}$ & $\begin{array}{c}\text { Stosunek liczbowy } \\
\text { żołnierzy katolickich } \\
\text { do protestanckich }\end{array}$ & $\begin{array}{l}\text { Kandydaci na kapelanów } \\
\text { wojskowych }\end{array}$ \\
\hline 1 & 2 & 3 & 4 & 5 \\
\hline 1 & Bartoszyce & 1 & $1 / 27$ & $\begin{array}{c}\text { wikariusz Joachim Hinz } \\
\text { z Lidzbarka Warmińskiego }\end{array}$ \\
\hline 2 & Domnowo & 4 & $1 / 9$ & $\begin{array}{c}\text { wikariusz Joachim Hinz } \\
\text { z Lidzbarka Warmińskiego }\end{array}$ \\
\hline 3 & Gąbin & 0 & - & $\begin{array}{c}\text { komendariusz Franz } \\
\text { Thiedig z Drangowskiego }\end{array}$ \\
\hline 4 & $\begin{array}{l}\text { Iławka } \\
\text { Pruska }\end{array}$ & 33 & $1 / 5$ & $\begin{array}{c}\text { wikariusz Joachim Hinz } \\
\text { z Lidzbarka Warmińskiego }\end{array}$ \\
\hline 5 & Kętrzyn & 26 & $1 / 15$ & $\begin{array}{l}\text { kaznodzieja Valentin } \\
\text { Gotzheim ze Świętej Lipki }\end{array}$ \\
\hline 6 & $\begin{array}{c}\text { Norden- } \\
\text { bork }\end{array}$ & 4 & $1 / 8$ & $\begin{array}{l}\text { kaznodzieja Valentin } \\
\text { Gotzheim ze Świętej Lipki }\end{array}$ \\
\hline 7 & Pasłęk & 3 & $1 / 8$ & $\begin{array}{l}\text { wikariusz Anton Eichhorn } \\
\text { z Elbląga }\end{array}$ \\
\hline 8 & Piława & 29 & 14 & $\begin{array}{c}\text { wikariusz Anton Freytag } \\
\text { z Królewca }\end{array}$ \\
\hline 9 & Ragneta & 23 & $1 / 6$ & $\begin{array}{c}\text { komendariusz Franz } \\
\text { Thiedig z Drangowskiego }\end{array}$ \\
\hline 10 & Srokowo & 8 & $1 / 5$ & $\begin{array}{c}\text { kaznodzieja Valentin } \\
\text { Gotzhein ze Świętej Lipki }\end{array}$ \\
\hline 11 & Szczytno & 3 & $1 / 8$ & $\begin{array}{l}\text { wikariusz Andreas Gross } \\
\text { z Biskupca Reszelskiego }\end{array}$ \\
\hline 12 & Tapiewo & 7 & $1 / 19$ & $\begin{array}{c}\text { wikariusz Anton Freytag } \\
\text { z Królewca }\end{array}$ \\
\hline 13 & Welawa & 27 & $1 / 10$ & $\begin{array}{c}\text { wikariusz Anton Freytag } \\
\text { z Królewca }\end{array}$ \\
\hline 14 & Węgorzewo & 2 & $1 / 12$ & $\begin{array}{c}\text { kaznodzieja Valentin } \\
\text { Gotzhein ze Świętej Lipki }\end{array}$ \\
\hline 15 & Wystruć & 21 & $1 / 15$ & $\begin{array}{c}\text { komendariusz Franz } \\
\text { Thiedig z Drangowskiego }\end{array}$ \\
\hline
\end{tabular}

Źródło: Geheimes Staatsarchiv Preussicher Kulturbesitz, Berlin-Dahlem, I. Hauptabteilung, Rep. 76 Kultusministerium IV, Sekt. 2, Abt. VIII, Nr. 1, Bd. 1, k. 8. 
Liczba katolickich żołnierzy na obszarze diecezji warmińskiej, których nie objęto regularną posługą duszpasterską, wynosiła 191. Najwięcej osób tego wyznania odbywało służbę wojskową w Piławie (29), a najmniej - w Gąbinie (0) i Bartoszycach (1). Największy stosunek liczbowy katolików do protestantów odnotowano w Iławce Pruskiej i Srokowie (jeden na pięciu). Poza Gąbinem najmniejszy stosunek liczbowy stwierdzono w Bartoszycach. W tym garnizonie na jednego katolika przypadało 27 protestantów. Jeśli chodzi o kandydatury na kapelanów, warto nadmienić, że w Ostródzie na ten urząd proponowano wikariusza Andreasa Wiecha z Olsztyna bądź komendariusza Michaela Jablonskiego z Grabowa pod Lubawą. Kandydatura Wiecha o tyle wydawała się niezrozumiała, że należał on do duchowieństwa warmińskiego, a Ostróda podlegała kościelnej jurysdykcji biskupa chełmińskiego. Podobnie było z proboszczem Bernhardem Elwartem z Dzierzgonia, który miał objąć kapelanię w Biskupcu Pomorskim, Iławie, Kisielicach, Prabutach, Suszu i Zalewie, czyli w miastach usytuowanych na obszarze diaspory diecezji chełmińskiej ${ }^{29}$.

Ministerstwo Wyznań Religijnych, Oświaty i Zdrowia nie wniosło zastrzeżeń w stosunku do kandydatur przedłożonych przez konsystorz królewiecki. Jeśli chodzi o rekompensatę, miała ona obejmować wyłącznie koszty podróży duchowieństwa. Ministerstwo nie zgodziło się na propozycję konsystorza, aby zrezygnować z opieki duszpasterskiej w garnizonach liczących od jednego do czterech katolików. Tłumaczono wówczas, że „nauczanie religijne oraz związane z nim pocieszenie wynikają z potrzeb człowieka” „([...] die Belehrungen und Tröstungen der Religion ein allgemein menschliches Bedürfniß sind $\left.[\ldots]^{\prime \prime}\right)^{30}$.

Tab. 6. Częstotliwość posługi sakramentalnej zamiejscowych kapelanów w garnizonach na obszarze diecezji warmińskiej (stan na 30 V 1833 r.)

\begin{tabular}{|c|c|c|c|c|}
\hline Lp. & Garnizon & Rodzaj jednostki korpusu & $\begin{array}{c}\text { Częstotliwość } \\
\text { posługi sa- } \\
\text { kramentalnej } \\
\text { w roku }\end{array}$ & Kapelan wojskowy \\
\hline 1 & 2 & 3 & 4 & 5 \\
\hline 1 & $\begin{array}{l}\text { Iławka } \\
\text { Pruska }\end{array}$ & $\begin{array}{l}\text { 1 Pododdział (Abteilung) } \\
1 \text { Kompanii Inwalidów }\end{array}$ & 2 & $\begin{array}{c}\text { wikariusz Joachim } \\
\text { Hinz z Lidzbarka } \\
\text { Warmińskiego }\end{array}$ \\
\hline 2 & Kętrzyn & I Batalion Strzelców & 2 & $\begin{array}{c}\text { kaznodzieja } \\
\text { Valentin Gotzhein } \\
\text { ze Świętej Lipki }\end{array}$ \\
\hline
\end{tabular}

${ }^{29}$ Ibid., k. 8.

${ }^{30}$ Ibid., k. 9-10. 


\begin{tabular}{|c|c|l|c|c|}
\hline 1 & 2 & \multicolumn{1}{|c|}{3} & 4 & 5 \\
\hline 3 & Piława & $\begin{array}{l}\text { kompania garnizonowa } \\
\text { 1 Pułku Piechoty, kompania } \\
\text { garnizonowa 3 Pułku Piechoty } \\
\text { oraz jedna z kompanii } \\
\text { 1 Dywizji }\end{array}$ & 1 & $\begin{array}{c}\text { wikariusz } \\
\text { Anton Freytag } \\
\text { z Królewca }\end{array}$ \\
\hline 5 & Ragneta & $\begin{array}{l}\text { kompania garnizonowa } \\
\text { II Batalionu (Abteilung) } \\
\text { 4 Pułku Piechoty }\end{array}$ & 2 & $\begin{array}{c}\text { komendariusz } \\
\text { Franz Thiedig } \\
\text { z Drangowskiego }\end{array}$ \\
\hline 6 & Welawa & $\begin{array}{l}\text { 1 i 2 Szwadron } \\
\text { 3 Pułku Kirasjerów }\end{array}$ & 2 & $\begin{array}{c}\text { wikariusz Anton } \\
\text { Freytag z Królewca }\end{array}$ \\
\hline Wystruć & $\begin{array}{l}\text { 1 i 2 Szwadron 1 Pułku } \\
\text { Dragonów oraz trzon (Stamm) } \\
\text { II Batalionu (Wystrucki) } \\
\text { 1 Pułku Landwehry }\end{array}$ & 2 & $\begin{array}{c}\text { Fomendariusz } \\
\text { z Drang Thiedig }\end{array}$ \\
\hline
\end{tabular}

Źródło: Geheimes Staatsarchiv Preussicher Kulturbesitz, Berlin-Dahlem, I. Hauptabteilung, Rep. 76 Kultusministerium IV, Sekt. 2, Abt. VIII, Nr. 1, Bd. 1, k. 13v-14.

Kapelani wojskowi odwiedzali garnizony $\mathrm{z}$ reguły dwa razy w ciągu roku. W $1833 \mathrm{r}$. ich pierwsza wizyta z posługą duszpasterską odbywała się tuż po Wielkanocy, która przypadała wówczas na 7 kwietnia. Ich drugi pobyt zaplanowano na październik ${ }^{31}$.W Piławie kapelan wojskowy sprawował sakramenty jedynie raz w roku, ponieważ po raz drugi żołnierze mogli brać udział w celebracjach liturgicznych, które niewymieniony z nazwiska duszpasterz odprawiał dla ludności cywilnej ${ }^{32}$. Warto nadmienić, że katolicką wikarię erygowano w tym mieście dopiero w 1910 r., natomiast kurację (czyli niepełnoprawną parafię) - w $1926 \mathrm{r} .{ }^{33} \mathrm{~W}$ dokumencie źródłowym odnoszącym się do powyższego zestawienia wymieniono jeszcze garnizony w Prabutach, Suszu i Zalewie, które dwa razy w roku odwiedzał proboszcz Elwart z Dzierzgonia ${ }^{34}$.

W połowie sierpnia 1835 r. biskup Hohenzollern powiadomił nadprezydenta Heinricha Theodora von Schöna o śmierci ks. Joachima Hinza, dotychczasowego proboszcza w Kraszewie, który posługiwał w garnizonach w Iławce Pruskiej i Domnowie. W duszpasterstwie wojskowym miał go zastąpić wikariusz Otto Radolinski z Lidzbarka Warmińskiego. Z kolei ks. Anton Freytag, będący kapelanem w Piławie, Tapiewie i Welawie, został przeniesiony z wikariatu w Królewcu do Braniewa. Jego dotychczasowe obowiązki powierzono

\footnotetext{
${ }^{31}$ Ibid., k. 14.

${ }^{32}$ Ibid.

${ }^{33}$ A. Корісzко, Duchowieństwo katolickie diecezji warmińskiej, s. 23.

${ }^{34}$ GStA PK, I. HA, Rep. 76 IV, Sekt. 2, Abt. VIII, Nr. 1, Bd. 1, k. 13v-14.
} 
królewieckiemu proboszczowi Franciszkowi Grossmannowi ${ }^{35}$. Tenże z kolei w 1841 r. otrzymał kanonię warmińską, co wiązało się z jego przeprowadzką do Fromborka. Posługę religijną wśród żołnierzy, zarówno w Królewcu, jak i Piławie oraz Welawie, przejęli królewieccy wikariusze. W następnym roku kapelanię wojskową zaproponowano nowo ustanowionemu proboszczowi królewieckiemu Augustowi J. Wunderowi ${ }^{36}$.

W 1842 r. kaznodzieja Valentin Gotzhein ze Świętej Lipki został komendariuszem w Barczewku. Funkcję kapelana obsługującego garnizony w Kętrzynie i Srokowie miał objąć po nim kaznodzieja Franz Krause, który zdaniem władz diecezjalnych znakomicie nadawał do tej pracy. Dowództwo wojskowe sugerowało jednak, aby zrezygnować $\mathrm{z}$ wizyt kapelana w kętrzyńskim garnizonie, ponieważ stacjonowała w nim niewielka liczba katolickich żołnierzy. Proponowano zatem, aby wydawać im przepustki na pobyt w Świętej Lipce, gdzie korzystaliby z posługi sakramentalnej. W Srokowie służbę pełniło również niewielu katolików, na dodatek starszych niż przeciętni żołnierze. Odległość do Świętej Lipki, gdzie mogliby przystąpić do sakramentów św., wynosiła jednak niemal cztery mile. Władze wojskowe dysponowały informacją, że do Srokowa przyjeżdżał rokrocznie katolicki duchowny, który celebrował mszę św. dla tamtejszej ludności cywilnej. Nic nie stało na przeszkodzie, aby również żołnierze brali udział w tej liturgii. Odwiedziny kaznodziei Krausego miały zatem umożliwić im skorzystanie z posługi sakramentalnej drugi raz w ciągu roku ${ }^{37}$. Tegoż roku ks. Franz Thiedig z Drangowskiego został proboszczem w Ornecie. Jego dotychczasową posadę objął ks. Anton Schmidt. Na życzenie biskupa Józefa Ambrożego Geritza wyraził on także gotowość opieki nad żołnierzami w Tylży i Wystruci ${ }^{38}$.

Kolejne zmiany dotyczące obsady kapelanii wojskowych spowodowała śmierć ks. dziekana Andreasa Rehaaga z Elbląga w 1842 r. Do czasu obsadzenia tego urzędu obowiązki kapelana wojskowego powierzono wikariuszowi Johannesowi K. Czachowskiemu. Nowym proboszczem elbląskim został rok później ks. Martin Müller. Biskup warmiński Józef Ambroży Geritz nie widział przeciwskazań, aby władze państwowe zaaprobowały kandydaturę tego duchownego na kapelana ${ }^{39}$. Śmierć proboszcza Bernharda Elwarta z Dzierzgonia spowodowała konieczność mianowania kapelana, który odwiedzałby żołnierzy w Prabutach, Suszu i Zalewie. W 1844 r. nowy proboszcz w tej parafii ks. Andreas Lingnau zadeklarował wolę objęcia obowiązków duszpasterza

\footnotetext{
${ }^{35}$ Ibid., k. 37.

${ }^{36}$ Ibid., k. 108-108v.

${ }^{37}$ Ibid., k. 100-100v.

${ }^{38}$ Ibid., k. 112.

${ }^{39}$ Ibid., k. 114.
} 
żołnierzy ${ }^{40}$. Tego roku z funkcji kapelana zrezygnował proboszcz z Ignalina ks. Otto Radolinski, który od 1835 r. opiekował się garnizonem w Iławce Pruskiej. Na jego stanowisko biskup warmiński desygnował wikariusza Josepha Setta z Lidzbarka Warmińskiego ${ }^{41}$.

W 1845 r. władze państwowe wyznaczyły proboszcza Petera Baranowskiego z Tychnowych na duszpasterza garnizonu w Kwidzynie. Odbyło się to zapewne za przyzwoleniem biskupa warmińskiego, chociaż miasto to podlegało diecezji chełmińskiej ${ }^{42}$. Ministerstwo Wojny nie zostało poinformowane, że w miejsce ks. Schmidta kapelanem w Tylży i Wystruci mianowano ks. Johannesa Zabermana, który podjął nowe obowiązki na początku $1847 \mathrm{r}$. W lutym $1849 \mathrm{r}$. wyruszył on z posługą duszpasterską do katolików mieszkających w Wystruci. Poza żołnierzami z tego miasta odwiedził również garnizon w Gąbinie, za co domagał się zwrotu kosztów podróży i diet ${ }^{43}$.

W 1848 r. ks. Andreas Lingnau z Dzierzgonia, który był kapelanem w Prabutach, Suszu i Zalewie, otrzymał nominację na proboszcza w Klebarku Wielkim. Rok później następny dzierzgoński proboszcz Joseph Jogalla zapowiedział, że przyjmie funkcję duszpasterza żołnierzy, jeśli zgodzą się na to władze państwowe ${ }^{44}$. Ostatecznie zaaprobowały one tę kandydaturę ${ }^{45}$.

\section{FINANSOWANIE DUSZPASTERZY WOJSKOWYCH}

Na początku 1833 r. informowano, że wolę dalszej pracy w charakterze kapelana wojskowego wyraził komendariusz Franz Thiedig z Drangowskiego, co jednak spotkało się z zastrzeżeniami ze strony członków konsystorza królewieckiego. Ksiądz ten roztoczył pastoralną opiekę nad żołnierzami z garnizonu w Tylży, która leżała ćwierć mili od jego miejsca zamieszkania. Stan tamtejszych dróg pozostawiał wiele do życzenia, dlatego potrzebował on wozu, aby odwiedzać $\mathrm{m}$.in. chorych z posługą sakramentalną. Konsystorz zamierzał zatem przyznać mu rekompensatę za posługę duszpasterską wśród tamtejszych żołnierzy. Wskazywał jednocześnie, że należy ją rozszerzyć na garnizony w Gąbinie, Ragnecie i Wystruci. Ministerstwo zaznaczało, że stawka takiej gratyfikacji będzie dość niska ${ }^{46}$.

Pół roku później konsystorz przytaczał opinię ks. Thiediga, który dopuszczał udział tylżyckich żołnierzy katolickich w liturgii sprawowanej w Drangowskim, ponieważ służbę odbywała niewielka ich liczba. Zabiegał jednak u władz

\footnotetext{
${ }^{40}$ Ibid., k. 116.

${ }^{41}$ Ibid., k. $118-118 \mathrm{v}$.

${ }^{42}$ Ibid., k. 122.

${ }^{43}$ Ibid., k. 123.

${ }^{44}$ Ibid., k. 127.

${ }^{45}$ Ibid., k. 128.

${ }^{46}$ Ibid., k. 5-5v.
} 
państwowych o stałą rekompensatę, której wartość, zgodnie z sugestią biskupa warmińskiego, opiewała na pięć talarów rocznie. Ani dowódcy szwadronów ze stacjonującego w Tylży 1 Pułku Dragonów, ani tamtejszego batalionu Landwehry, nie potrafili jednak sprecyzować, jaki rodzaj posługi kapłańskiej wymagał gratyfikacji. Na chrzest, ślub, czy też do sakramentu komunii św. tylżyckim żołnierzom udzielano przepustek. Konsystorz proponował zatem, aby wypłacać mu należność finansową za każde odwiedziny chorych w wojskowym lazarecie $^{47}$. Ostatecznie Ministerstwo Wyznań Religijnych, Oświaty i Zdrowia opowiedziało się za przyznaniem mu rocznej rekompensaty o wartości pięciu talarów, co jednak nie przełożyło się na wynagrodzenie innych kapelanów ${ }^{48}$.

Sprawy dotyczącej wypłaty rekompensat nie rozstrzygnięto jeszcze jesienią 1834 r. ${ }^{49}$ Z kolei w lutym 1835 r. minister wojny Job von Witzleben potwierdził, że katoliccy kapelani otrzymują diety, zwrot kosztów podróży, a także cztery talary za posługę kapłańską („kirchlicher Act”). Nieco wcześniej z funduszy wojskowych otrzymywali oni rekompensatę za utrzymanie i naprawę paramentów oraz szat liturgicznych ${ }^{50}$. Minister wyznań Karl von Altenstein sugerował zachowanie tej płatności bądź pozyskanie przez wojsko własnych paramentów i szat ${ }^{51}$. Pertraktacje $\mathrm{w}$ tej sprawie $\mathrm{z}$ pewnością toczyły się wcześniej z biskupem warmińskim. Ministerstwo Wojny utrzymywało, że 14 VI 1834 r. hierarcha ten podjął decyzję o przekazaniu na własność fiskusa wojskowego szat i paramentów, które poddano pracom naprawczym sfinansowanym $\mathrm{z}$ funduszy państwowych ${ }^{52}$. Ich koszt wynosił 21 talarów i jednego srebrnego grosza ${ }^{53}$.

Na zakończenie warto nadmienić, że przeszkodą w działalności duszpasterstwa wojskowego był brak odpowiednich paramentów do sprawowania nabożeństw w garnizonach. Większość miast garnizonowych, pozbawionych katolickiego kapelana, znajdowała się na obszarze diaspory. Rzadko kiedy posługiwali w nich księża katoliccy, ponieważ tworzenie nowych placówek duszpasterskich skutecznie utrudniały władze państwowe aż do przyjęcia oktrojowanej konstytucji w 1850 r. Duchowni z nielicznych parafii w diasporze katolickiej mieli na dodatek niewielkie uposażenie, dlatego nie mogli sobie pozwolić na fundowanie wyposażenia liturgicznego w garnizonach. W związku z tym biskup warmiński Józef Hohenzollern zaproponował, żeby brakujące utensylia przekazać kapelanom wojskowym ze skasowanego klasztoru

\footnotetext{
${ }^{47}$ Ibid., k. 19-19v.

${ }^{48}$ Ibid., k. 21-21v.

${ }^{49}$ Ibid., k. 27.

${ }^{50}$ Ibid., k. 30.

${ }^{51}$ Ibid., k. 31-31v.

${ }^{52}$ Ibid., k. 34.

${ }^{53}$ Ibid., k. 35-35v.
} 
w Stoczku Warmińskim. Ministerstwo Wyznań Religijnych, Oświaty i Zdrowia uznało ten pomysł za uzasadniony ${ }^{54}$. Podkreślano jednak, że z reguły księża starali się o alby. Niestety, w likwidowanych klasztorach też ich brakowało ${ }^{55}$.

Mimo braku trwałych rozwiązań dotyczących katolickiego duszpasterstwa wojskowego w Prusach w pierwszej połowie XIX w. żołnierzom umożliwiono dostęp do posługi religijnej. Na obszarze diecezji warmińskiej, w przypadku miejscowości garnizonowych, w których znajdowały się katolickie placówki duszpasterskie, korzystali oni z posługi miejscowego księdza diecezjalnego. Do wielu jednostek wojskowych udawał się dwa razy w roku duchowny, który otrzymywał delegację od biskupa warmińskiego oraz akceptację władz państwowych. Wreszcie w kilku garnizonach udzielano żołnierzom przepustek, aby mogli przystąpić do sakramentów świętych w kościołach leżących poza miejscem odbywania przez nich służby wojskowej.

Wskutek przemian spowodowanych Wiosną Ludów władze pruskie podporządkowały zarówno wszystkich katolickich żołnierzy, jak i kapelanów jurysdykcji kościelnej biskupa wrocławskiego. Pius IX potwierdził tę decyzję w brewe Venerabilis Pater, opublikowanym 24 X 1849 r. Sprawami duszpasterstwa wojskowego miał zarządzać delegat wspomnianego ordynariusza. Biskup Melchior von Diepenbrock 19 II 1852 r. mianował nim ks. Feliksa Menckego, który został pierwszym proboszczem polowym w państwie pruskim ${ }^{56}$.

\section{Bibliografia}

Claessen, J. M., Andreas Räs and Nikolaus von Weis. Beiträge zur Kirchengeschichte des neuesten Jahrhunderts in Deutschland oder über die neuesten kirchlichen Verhältnisse daselbst. Augsburg: Kollmann, 1835.

Güsgen, Johannes. Die katholische Militärseelsorge in Deutschland zwischen 1920 und 1945. Köln, Wien: Böhlau Verlag, 1989.

Huber, Ernst R. and Wolfgang Huber. Staat und Kirche im 19. und 20. Jahrhundert. Dokumente zur Geschichte des deutschen Staatskirchenrechts, vol. 1: Staat und Kirche vom Ausgang des alten Reichs bis zum Vorabend der bürgerlichen Revolution. Berlin: Duncker \& Humblot, 1990.

${ }^{54}$ Ibid., k. 6. O przekazaniu kapelanom wojskowym części naczyń i szat liturgicznych ze Stoczka Warmińskiego wspomina Konrad Sarwa, Kult Najświętszej Maryi Panny Matki Pokoju w Stoczku Warmińskim do 1920 r., Studia Warmińskie, t. 21: 1984, s. 136.

${ }^{55}$ GStA PK, I. HA, Rep. 76 IV, Sekt. 2, Abt. VIII, Nr. 1, Bd. 1, k. 10v.

${ }^{56}$ Ibid., k. 129-129v; A. KopIczko, Duchowieństwo katolickie diecezji warmińskiej, s. 191-192. 
Jodkowski, Marek. "Dzieje placówki duszpasterskiej w Piszu przed II wojną światową.” Studia Ełckie 14 (2012): 233-245.

Jodkowski, Marek. "Katolicka parafia w Tylży w XIX wieku." Studia Redemptorystowskie 13 (2015): 357-371.

Kolberg, Augustin. "Geschichte der Heiligenlinde." Zeitschrift für die Geschichte und Altertumskunde Ermlands 3 (1866): 28-138, 435-520.

Kopiczko, Andrzej. Duchowieństwo katolickie diecezji warmińskiej $w$ latach 1821-1945, vol. 1: Studium prozopograficzne. Olsztyn: Wydział Duszpasterski Kurii Metropolitalnej Archidiecezji Warmińskiej, 2004.

Kopiczko, Andrzej. "Rozwój Kościoła katolickiego na terytorium dzisiejszego Obwodu Kaliningradzkiego (do 1947 r.). Zarys problematyki." In Czynem i prawdą. Ksiegga pamiątkowa na siedemdziesiąte piąte urodziny księdza arcybiskupa Edmunda Piszcza, edited by Cyprian Rogowski, Władysław Nowak and Andrzej Kopiczko, 99-118. Olsztyn: Hosianum, 2004.

Kopiczko, Andrzej. Ustrój i organizacja diecezji warmińskiej w latach 15251772. Olsztyn: Ośrodek Badań Naukowych im. Wojciecha Kętrzyńskiego, 1993.

Pohl, Heinrich. Die katholische Militärseelsorge Preussens 1797-1888. Amsterdam: P. Schippers, 1962.

Sarwa, Konrad. "Kult Najświętszej Maryi Panny Matki Pokoju w Stoczku Warmińskim do 1920 r.” Studia Warmińskie 21 (1984): 100-159. 